\title{
Decreased T-suppressor cell activity in rats with adjuvant arthritis
}

\author{
LISE BINDERUP
}

From the Department of Pharmacology, Leo Pharmaceutical Products, DK-2750 Ballerup, Denmark

SUMmARY Concanavalin-A-induced T-suppressor cell activity was decreased in spleen cell suspensions from Lewis rats with adjuvant arthritis. This decreased activity was evident on day 10 after the induction of the disease, just before the development of the polyarthritic lesions, and persisted during the period of active inflammatory and immunological disease. The extent of the impairment of T-suppressor cell activity was positively correlated with the severity of the arthritic lesions. Removal of phagocytic cells prior to induction of T-suppressor cells abolished the observed decrease in suppressor cell activity. It is suggested that this model may be of value for the investigation of suppressor cell function in immunologically mediated disorders.

Recent investigations have suggested that defective T-suppressor cell activity may be implicated in the pathogenesis of diseases characterised by aberrant immunological reactivity. In patients with rheumatoid arthritis a decrease in the number of suppressor/cytotoxic T-cells in peripheral blood and synovial fluid has been observed, ${ }^{1}$ and concanavalin-A (con-A)-induced T-supressor cell activity is markedly deficient in rheumatoid synovial lymphocytes. ${ }^{2}$ In addition, loss of suppressor cell activity has been described in juvenile rheumatoid arthritis, ${ }^{3}$ systemic lupus erythematosus, ${ }^{4}$ chronic active hepatitis, ${ }^{5}$ multiple sclerosis, ${ }^{6}$ autoimmune thyroiditis, ${ }^{7}$ primary biliary cirrhosis, ${ }^{8}$ and inflammatory bowel disease. ${ }^{9}$

Investigation into the mechanism of action and the regulation of the suppressor cells during immunological disease is hampered by the lack of suitable animal models. The most widely used model is the murine lupus developing in NZB/NZW $F_{1}$ mice. ${ }^{10}$ In these mice $\mathrm{T}$-suppressor cell activity is lost with age, thereby allowing the development of autoimmune manifestations. ${ }^{11}$ But long periods of induction and observation are necessary, as overt disease is first noted at 4 to 6 months of age.

In the present experiments the induction of T-suppressor cell activity was investigated following the induction of a chronic inflammatory disease-namely, adjuvant arthritis-in rats. This model of experimentally induced polyarthritis mimicks some of the features of rheumatoid arthritis

Accepted for publication 11 January 1983.

Correspondence to Dr L. Binderup. in man, ${ }^{12}$ and recent experiments have shown that cell-mediated immunity and immunoregulatory functions are altered during the course of the disease..$^{13} 14$ In contrast to control rats, rats with adjuvant arthritis were found to have decreased con-A-induced T-suppressor cell activity 2 to 4 weeks after the induction of the disease. The development of defective T-suppressor cell activity coincided with the development of the polyarthritic lesions and was positively correlated with the severity of the lesions.

\section{Materials and methods}

Induction of adjuvant arthritis. Adjuvant arthritis was induced in female inbred Lewis rats (160-200 g) by injecting $0.3 \mathrm{mg}$ of heat-killed Mycobacterium butyricum (Difco) suspended in $0.1 \mathrm{ml}$ of mineral oil in to the footpad of the right hind paw. In one series of investigations this treatment was repeated on day 7 after the initial injection of adjuvant. Nonarthritic rats matched for weight and age served as controls. The severity of the induced polyarthritis was assessed by measuring the volume of the injected and noninjected hind paws by a mercury displacement plethismometer. The intensity of the reaction was calculated as the difference between the paw volume on the day of measurement and on the day of adjuvant injection, and was expressed as mean \pm SD ml of oedemà.

Induction and assay of T-suppressor cells. Spleens were removed from control and arthritic rats and cell suspensions were prepared individually from each rat. All manipulations were performed at $4^{\circ} \mathrm{C}$ to avoid loss of adherent cells. Cell suspensions were 
adjusted to $20 \times 10^{6}$ nucleated cells $/ \mathrm{ml}$ in Rosewell Park Memorial Institute (RPMI) medium 1640 (Gibco), supplemented with $2 \mathrm{mM}$ glutamine, 100 units $/ \mathrm{ml}$ penicillin, $100 \mu \mathrm{g} / \mathrm{ml}$ streptomycin, and $10 \%$ fetal calf serum (Gibco). Aliquots of $1 \mathrm{ml}$ were cultured at $37^{\circ} \mathrm{C}$ in $5 \% \mathrm{CO}_{2}$ in air in tissue-culturetreated plastic Petri dishes (Nunc, Denmark). 0 or 5 $\mu \mathrm{g} / \mathrm{ml}$ con-A, grade IV (Sigma) was added to the cultures. $24 \mathrm{~h}$ later the nonadherent cells were collected, washed, and treated with $30 \mu \mathrm{g} / \mathrm{ml}$ mitomycin-C (Sigma) for $30 \mathrm{~min}$ at $37^{\circ} \mathrm{C}$. The cells were washed, counted, and adjusted to $4 \times 10^{6}$ cells/ml. Cell viability was determined by the eosin $Y$ exclusion method and expressed as \% viable cells \pm SD for each experimental group. Aliquots of $50 \mu \mathrm{l}$ of the cell suspensions were added to freshly prepared cultures containing $100 \mu \mathrm{l}$ Lewis spleen cells and 100 $\mu$ l Lewis $\times$ Brown Norway $\left(F_{1}\right)$ spleen cells $\left(4 \times 10^{6}\right.$ cells $/ \mathrm{ml}$ in culture medium supplemented with $5 \times 10^{-5} \mathrm{M}$ 2-mercaptoethanol). The cultures were incubated for $96 \mathrm{~h}$ at $37^{\circ} \mathrm{C}$ in flat-bottomed tissueculture-treated microtitration plates (Nunc, Denmark). Four hours before the end of incubation 1 $\mu \mathrm{Ci} / \mathrm{ml}^{3} \mathrm{H}$-thymidine $\left({ }^{3} \mathrm{H}\right.$-TdR, $5000 \mathrm{mCi} / \mathrm{mmol}$, the Radiochemical Centre, Amersham, England) was added to each culture. After being labelled the nonadherent cells were aspirated from the culture wells into $12 \%$ ice-cold trichloroacetic acid (TCA), and the amount of radioactivity incorporated in the DNA was determined as already described. ${ }^{15}$ The uptake of ${ }^{3} \mathrm{H}$-TdR by the remaining adherent cells in the culture wells was determined after digestion of the cells with $0.5 \mathrm{~N} \mathrm{NaOH}$. This uptake always accounted for less than $3 \%$ of the uptake by the nonadherent cells. The viability of the cells was determined at the end of incubation by the eosin Y exclusion method. The results were expressed as dis- integrations per minute $(\mathrm{dpm}) /$ culture \pm SEM. All determinations were performed in triplicate, and Student's $t$ test was used for statistical analysis.

Removal of phagocytic cells. In some experiments phagocytic cells were removed from the spleen cell suspensions prior to induction of T-suppressor cells with con-A. Spleen cells were adjusted to $20 \times 10^{6}$ cells $/ \mathrm{ml}$ and treated with carbonyl iron particles $(20$ $\mathrm{mg} / \mathrm{ml}$ for $30 \mathrm{~min}$ at $37^{\circ} \mathrm{C}$ ). Iron-ingesting cells were removed with a large magnet, and the depleted cells were washed, counted, and readjusted to $20 \times 10^{6}$ cells $/ \mathrm{ml}$. The distribution of lymphocytes and macrophages was determined before and after treatment with carbonyl iron by Giemsa/May Grünwald staining and by staining for nonspecific membraneassociated esterase by the method of Yam et al. ${ }^{16}$

\section{Results}

INDUCTION OF T-SUPPRESSOR CELLS

T-suppressor cells were induced with con-A (5 $\mu \mathrm{g} / \mathrm{ml}$ ) using unseparated spleen cells obtained from control Lewis rats and from Lewis rats with adjuvant arthritis 17 days after the induction of the disease. The cells were tested for their ability to suppress the mixed lymphocyte reaction (MLR) in cultures of Lewis and Lewis $\times \mathrm{BN}\left(\mathrm{F}_{1}\right)$ control rats. Table 1 shows that con-A-induced spleen cells from control rats could significantly inhibit ${ }^{3} \mathrm{H}-\mathrm{TdR}$ incorporation in MLR cultures compared with cultures without added cells $(44 \%$ inhibition, $\mathrm{p}<0.001)$ and compared with cultures with cells incubated without con-A ( $35 \%$ inhibition, $p<0 \cdot 005)$. On the contrary no inhibition was observed when con-A-induced spleen cells from arthritic rats were added to the MLR cultures ( $2 \%$ inhibition, NS). Increasing the concentration of con-A to $10 \mu \mathrm{g} / \mathrm{ml}$ or increasing the

Table 1 Induction of T-suppressor cells with con-A

\begin{tabular}{lllll}
\hline $\begin{array}{l}\text { Cultures for } \\
\text { suppressor cell } \\
\text { induction }\end{array}$ & $\begin{array}{l}\text { Con-A } \\
\text { treatment } \\
\mu g / m l\end{array}$ & $\begin{array}{l}\text { s H-TdR incorporation } \\
\text { in } M L R \\
d p m / \text { culture } \pm S E M\end{array}$ & $\begin{array}{l}\text { \% Change } \\
\text { in }{ }^{3} H-T d R \\
\text { incorporation }\end{array}$ & $p$ \\
\hline No cells & - & $113173 \pm 8774$ & \\
$\begin{array}{l}\text { Control } \\
\text { spleen cells }\end{array}$ & 0 & $98177 \pm 6892$ & -35 & $<0 \cdot 005$ \\
$\begin{array}{l}\text { Arthritic } \\
\text { spleen cells }\end{array}$ & 5 & $63519 \pm 5872$ & & NS \\
\hline
\end{tabular}

Spleen cell suspensions were prepared from control and arthritic Lewis rats on day 17 after the induction of the disease. After incubation for $24 \mathrm{~h}$ with con-A $(0$ or $5 \mu \mathrm{g} / \mathrm{ml})$, the cells were washed, treated with mitomycin-C, and added to MLR cultures of Lewis and Lewis $\times$ Brown Norway $\left(F_{1}\right)$ spleen cells. ${ }^{3} \mathrm{H}$-TdR incorporation was determined after $96 \mathrm{~h}$ of culture and expressed as mean dpm/culture \pm SEM of 9 separate experiments. The $p$ value indicates a significant difference in ${ }^{3} \mathrm{H}$-TdR incorporation between cultures supplemented with con-A-induced cells and cultures supplemented with cells without con-A pretreatment. NS=not significant. 
Table 2 Time course of suppressor $T$-cell induction

\begin{tabular}{|c|c|c|c|c|c|}
\hline $\begin{array}{l}\text { Cultures for } \\
\text { suppressor cell } \\
\text { induction }\end{array}$ & $\begin{array}{l}\text { Con-A } \\
\text { treatment } \\
\mu \mathrm{g} / \mathrm{ml}\end{array}$ & $\begin{array}{l}\text { Noninjected paw } \\
\text { ml oedema, } \\
\text { mean } \pm S D\end{array}$ & $\begin{array}{l}{ }^{3} \mathrm{H}-\mathrm{TdR} \text { incorporation } \\
\text { in } M L R \\
\text { dpm/culture } \pm S E M\end{array}$ & $\begin{array}{l}\text { \% Change } \\
\text { in }{ }^{3} H-T d R \\
\text { incorporation }\end{array}$ & $p$ \\
\hline \multirow{2}{*}{$\begin{array}{l}\text { Control } \\
\text { spleen cells } \\
(n=24)\end{array}$} & 0 & \multirow[b]{2}{*}{0} & $97481 \pm 4316$ & & \\
\hline & 5 & & $54883 \pm 4315$ & -44 & $<0.001$ \\
\hline \multirow{2}{*}{$\begin{array}{l}\text { Arthritic } \\
\text { spleen cells }(+4 d) \\
(n=3)\end{array}$} & 0 & \multirow[b]{2}{*}{0} & $52060 \pm 6814$ & & \\
\hline & 5 & & $36289 \pm 2694$ & -30 & NS \\
\hline \multirow{2}{*}{$\begin{array}{l}\text { Arthritic } \\
\text { spleen cells }(+10 d) \\
(n=6)\end{array}$} & 0 & \multirow{2}{*}{$0.12 \pm 0.03$} & $93112 \pm 8667$ & & \\
\hline & 5 & & $83300 \pm 7041$ & -11 & NS \\
\hline \multirow{2}{*}{$\begin{array}{l}\text { Arthritic } \\
\text { spleen cells }(+17 d) \\
(n=6)\end{array}$} & 0 & \multirow{2}{*}{$0.75 \pm 0.57$} & $109623 \pm 6554$ & & \\
\hline & 5 & & $106320 \pm 5894$ & -3 & NS \\
\hline \multirow{2}{*}{$\begin{array}{l}\text { Arthritic } \\
\text { spleen cells }(+24 d) \\
(n=6)\end{array}$} & 0 & \multirow{2}{*}{$0.85 \pm 0.97$} & $80748 \pm 7684$ & & \\
\hline & 5 & & $84340 \pm 4417$ & +4 & NS \\
\hline \multirow{2}{*}{$\begin{array}{l}\text { Arthritic } \\
\text { spleen cells }(+45 d) \\
(n=6)\end{array}$} & 0 & \multirow[b]{2}{*}{$0 \cdot 44 \pm 0.40$} & $86354 \pm 9408$ & & \\
\hline & 5 & & $63277 \pm 3614$ & -27 & $<0.05$ \\
\hline
\end{tabular}

Spleen cell suspensions were prepared from control and arthritic Lewis rats $4,10,17,24$, and 45 days after the induction of the disease. T-suppressor cells were induced with con-A $(0$ or $5 \mu \mathrm{g} / \mathrm{ml})$ and tested for their inhibitory effect on ${ }^{3} \mathrm{H}$-TdR incorporation in MLR cultures of Lewis and Lewis $\times \mathrm{BN}\left(\mathrm{F}_{1}\right)$ spleen cells. Disease severity was measured as the increase in the noninjected hind paw $(\mathrm{ml}$ oedema). $\mathrm{n}=\mathrm{Number}$ of rats tested. The results were expressed as described in the legend to Table 1.

number of added suppressor cells did not change this pattern of responsiveness (results not shown). No differences were found in cell viability after treatment with con- $\mathrm{A}$ and mitomycin-C (control cells: $76 \pm 11 \%$ viable cells; arthritic cells: $70 \pm 9 \%$ viable cells). Cell viability at the end of incubation was $54 \pm 8 \%$ in MLR cultures with control suppressor cells and $52 \pm 6 \%$ in MLR cultures with arthritic suppressor cells.

TIME COURSE OF T-SUPPRESSOR CELL IN DUCTION

In order to analyse the induction of $\mathrm{T}$-suppressor cells during the development and course of the arthritic disease spleen cell suspensions were prepared from arthritic rats on day 4 after adjuvant injection (primary inflammatory lesions of the injected paw), on day 10 (before the first signs of polyarthritis), on day 17 and 24 (established chronic inflammatory disease), and on day 45 (remission of inflammation and establishment of permanent articular damage). Table 2 shows that on day 4 con-A-induced arthritic spleen cells were less inhibitory (30\% inhibition) than the corresponding control spleen cells ( $44 \%$ inhibition). From day 10 to day 24 arthritic spleen cells could not significantly inhibit MLR cultures, whereas by day 45 the presence of T-suppressor cell activity was again observed $(27 \%$ inhibition, $\mathrm{p}<0.05)$.

CORRELATION OF T-SUPPRESSOR CELL

INDUCTION WITH DISEASE SEVERITY

Considerable variations were observed in disease severity of individual Lewis rats when injected with adjuvant. This is exemplified by the large standard deviations of the mean oedema of the noninjected hind paws, shown in Table 2 . In order to analyse whether disease severity was correlated with defective T-suppressor cell induction, spleen cell suspensions were prepared from groups of arthritic rats with small increases of noninjected hind paws (low responders) and from groups of arthritic rats with large increases (high responders). In addition spleen cell suspensions were also prepared from rats having received a second booster injection of adjuvant 7 days after the initiating injection. All spleen cells were collected on day 17 after the induction of the disease. Table 3 shows that low responder rats (mean oedema of the noninjected paw $0.23 \pm 0.12 \mathrm{ml}$ ) had a slight reduction of their suppressor cell activity ( $22 \%$ inhibition), compared with the corresponding cells from control rats ( $41 \%$ inhibition). High responder rats $(1.55 \pm 0.54 \mathrm{ml}$ oedema) had no suppressor cell activity, and cells from rats receiving 2 
Table 3 Con-A-induced T-suppressor cells in adjuvant arthritis: correlation with the severity of the disease

\begin{tabular}{|c|c|c|c|c|c|c|}
\hline \multirow{2}{*}{$\begin{array}{l}\text { Treatment } \\
\text { of rats }\end{array}$} & Injected paw & Noninjected paw & \multirow{2}{*}{$\begin{array}{l}\text { Induction of } \\
\text { suppressor } \\
\text { cells with } \\
\text { con- } A \\
(\mu g / m l)\end{array}$} & \multirow{2}{*}{$\begin{array}{l}{ }^{3} H-T d R \\
\text { incorporation } \\
\text { in } M L R \\
d p m / \text { culture } \\
\pm S E M\end{array}$} & \multirow{2}{*}{$\begin{array}{l}\text { \% Change } \\
\text { in }{ }^{3} H-T d R \\
\text { incorporation }\end{array}$} & \multirow[t]{2}{*}{$p$} \\
\hline & & $\begin{array}{l}\text { ml oedema } \\
\text { mean } \pm S D\end{array}$ & & & & \\
\hline $\begin{array}{l}\text { Controls } \\
(n=3)\end{array}$ & - & - & $\begin{array}{l}0 \\
5\end{array}$ & $\begin{array}{l}74060 \pm 2580 \\
44050 \pm 4780\end{array}$ & -41 & $<0.01$ \\
\hline $\begin{array}{l}\text { Adj arthritis } \\
\text { low responders } \\
(n=3)\end{array}$ & $2 \cdot 17 \pm 0 \cdot 63$ & $0 \cdot 23 \pm 0 \cdot 12$ & $\begin{array}{l}0 \\
5\end{array}$ & $\begin{array}{l}70252 \pm 4253 \\
55014 \pm 2475\end{array}$ & -22 & $<0.05$ \\
\hline $\begin{array}{l}\text { Adj arthritis } \\
\text { high responders } \\
(\mathrm{n}=3)\end{array}$ & $2 \cdot 38 \pm 0 \cdot 52$ & $1 \cdot 55 \pm 0.54$ & $\begin{array}{l}0 \\
5\end{array}$ & $\begin{array}{l}89324 \pm 7864 \\
89522 \pm 3622\end{array}$ & 0 & NS \\
\hline $\begin{array}{l}\text { Adj arthritis } \\
2 \times \text { adjuvant } \\
(\mathrm{n}=3)\end{array}$ & $2 \cdot 48 \pm 0 \cdot 07$ & $1 \cdot 82 \pm 0 \cdot 86$ & $\begin{array}{l}0 \\
5\end{array}$ & $\begin{array}{l}56788 \pm 7396 \\
74338 \pm 9359\end{array}$ & +31 & NS \\
\hline
\end{tabular}

Spleen cells were collected from control and arthritic Lewis rats 17 days after the induction of the disease. Rats were grouped according to the severity of the disease as measured by the increase in the volume of the noninjected hind paw. T-suppressor cells were induced with con- $\mathbf{A}(0$ or $5 \mu \mathrm{g} / \mathrm{ml}$ ) and tested for their inhibitory effect on ${ }^{3} \mathrm{H}-\mathrm{TdR}$ incorporation in MLR cultures of Lewis and Lewis $\times$ BN $\left(F_{1}\right)$ spleen cells. $\mathrm{n}=$ Number of rats in each group. The results were expressed as described in the legend to Table 1.

injections of adjuvant $(1.82 \pm 0.86 \mathrm{ml}$ oedema) actually increased ${ }^{3} \mathrm{H}$-TdR incorporation when added to MLR cultures. This increase did not, however, reach statistical significance. No correlation was observed between the level of suppressor cell activity and the magnitude of the inflammatory lesions of the injected hind paws.

\section{T-SUPPRESSOR CELL INDUCTION AND \\ REMOVAL OF PHAGOCYTIC CELLS}

The influence of the cells of the monocyte/macrophage lineage on the induction of $\mathrm{T}$-suppressor cells was next studied. Phagocytic cells were removed from control and arthritic spleen cell suspensions by treatment with carbonyl iron particles prior to induction with con-A. This treatment resulted in a recovery of $66 \pm 5 \%$ of the control cells and $63 \pm 5 \%$ of the arthritic cells. Less than $1 \%$ of the recovered cells were found to be monocytes/macrophages as determined by staining for nonspecific membraneassociated esterase. All cell suspensions contained $86 \pm 7 \%$ viable cells. Figure 1 shows that the removal of phagocytic cells from control spleen cell suspensions did not affect the subsequent induction of T-suppressor cells. On the other hand the removal of phagocytic cells from arthritic spleen cell suspensions abolished the previously observed defective induction of T-suppressor cells and resulted in an inhibition of ${ }^{3} \mathrm{H}-\mathrm{TdR}$ incorporation in MLR cultures comparable to that observed with the corresponding control spleen cells $(42 \%$ and $34 \%$ inhibition, respectively).

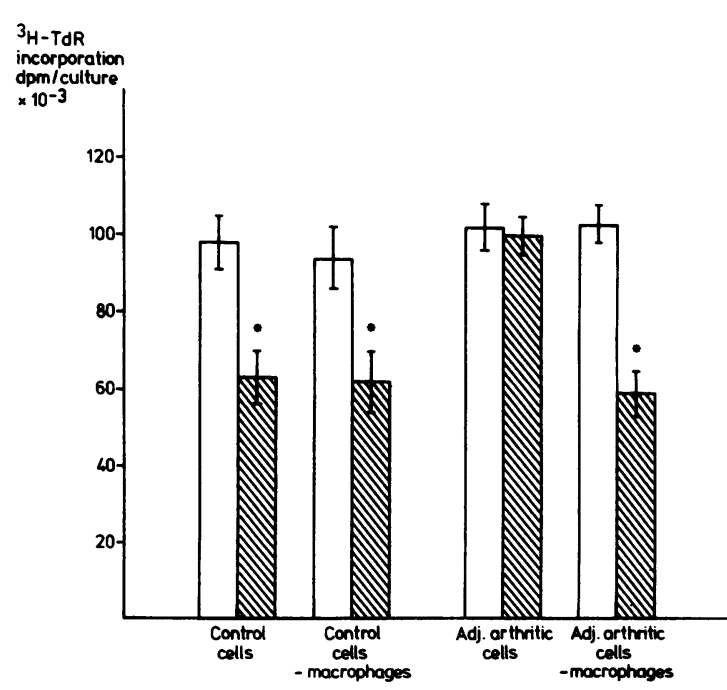

Fig. 1 Removal of phagocytic cells. Spleen cell suspensions were prepared from control and arthritic Lewis rats 17 days after the induction of the disease. Half of each cell suspension was treated with carbonyl iron to remove phagocytic cells (macrophages) prior to induction with con-A. The induced T-suppressor cells were added to $M L R$ cultures of Lewis and Lewis $\times B N(F$, spleen cells. The columns show the ${ }^{3} H-T d R$ incorporation in the $M L R$ cultures as mean dpm/culture $\pm S E M$. Number of rats tested in each group $=9$. Unshaded $=0 \mu \mathrm{g} / \mathrm{ml}$ con- $A$, shaded $=5$ $\mu \mathrm{g} / \mathrm{ml}$ con- $A$. The asterisks indicate a significant difference in ${ }^{3} \mathrm{H}-\mathrm{TdR}$ incorporation in cultures supplemented with con-A-induced cells, compared with the corresponding cultures with cells without con-A-pretreatment. 


\section{Discussion}

Adjuvant arthritis is a chronic polyarthritis induced in rats by the injection of Mycobacterium butyricum in mineral oil. The disease is believed to be due to an immunological process, possibly involving a delayed hypersensitivity reaction to disseminated antigenic constituents of the mycobacteria ${ }^{17}$ and/or an autoimmune reaction to homologous cell-bound antigens. ${ }^{18} 19$ The presence of a genetically determined basis for the susceptibility of the various rat strains to develop the disease has led to the suggestion that the disease process may be linked to defects in immunoregulatory functions. ${ }^{20}$

In the present experiments the induction of $\mathrm{T}$-suppressor cell activity in vitro was investigated by means of spleen cells from Lewis rats with adjuvant arthritis. T-suppressor cells were induced with mitogenic doses of con-A and tested for their ability to inhibit the mixed lymphocyte reaction in cultures of Lewis and Brown Norway $\left(F_{1}\right)$ rat spleen cells. T-suppressor cells prepared from arthritic rats 17 days after the induction of the disease could not inhibit the MLR, whereas significant inhibition was exerted by $\mathrm{T}$-suppressor cells from control rats. This difference in suppressor cell induction could not be abolished by increasing the number of suppressor cells or by changing the con-A concentration, nor could it be attributed to differences in cell survival.

Analysis of the course of induction of T-suppressor cells during the different phases of the disease showed that a significant decrease in T-suppressor cell activity was found already 10 days after the induction of the disease, just before the development of the polyarthritic lesions. During the phase of chronic inflammation with marked arthritic involvement of the joints T-suppressor cell activity could not be induced. T-suppressor cell activity was found to return towards control values on day 45 , at the time of remission of the chronic inflammation and establishment of permanent articular deformity. In addition rats which developed the most severe polyarthritic lesions, as measured by the oedema of the noninjected hind paw, had significantly less $\mathrm{T}$-suppressor cell activity than rats with less severe disease. The most marked impairment of T-suppressor cell activity was observed in rats receiving a second challenge with adjuvant, a treatment that may give rise to severe systemic changes of the disease. ${ }^{21}$ These results suggest that rats with adjuvant arthritis may fail to establish a normal level of T-suppressor cell activity on antigenic stimulation and that this defect may contribute both to the development and to the chronicity of the polyarthritic lesions.

Several mechanisms may contribute to this decrease in con-A-induced T-suppressor cell activity.
Precursor T-cells may be resistant to induction, or their relative number may be decreased in the spleen cell suspensions. Alternatively, other cell types may interfere with the normal induction of T-suppressor cells, pointing to a change or a defect in immunoregulatory pathways. Previous studies have shown that the function of macrophages is altered during the course of adjuvant arthritis. ${ }^{13}{ }^{14}$ Shortly after the induction of the disease suppressive macrophages were found in the spleen and lymph nodes; these cells could inhibit the response of lymphocytes to both $\mathrm{T}$ - and B-cell mitogens. It was therefore considered of interest to investigate whether macrophages were involved in the decrease in con-Ainduced T-suppressor cell activity in rats with adjuvant arthritis. Removal of macrophages with carbonyl iron particles prior to induction of T-suppressor cells resulted in complete restoration of suppressor cell activity. These results indicate that T-lymphocytes from arthritic rats have a normal capacity to express suppressor cell activity, but that the presence of macrophages interfere with this capacity. The macrophages may exert a direct inhibitory effect on T-precursor cells via cell-to-cell contact or via the release of soluble inhibitors. Regulation of macrophage function may further be controlled by subpopulations of immunoregulatory lymphocytes. These diverse mechanisms of lymphocytemacrophage co-operation are investigated in an accompanying paper. ${ }^{22}$

In conclusion, this paper describes a model of defective T-suppressor cell activity linked with the appearance of immunologically mediated polyarthritic lesions. The disease is rapidly and easily induced and may serve as a valuable model for the investigation of suppressor cell activity during chronic inflammatory disease. In addition the model has obvious potential for the investigation of the mechanism of action of drugs used in the treatment of immunological diseases.

The author thanks Professor E. Arrigoni-Martelli for helpful advice and discussion. The valuable technical assistance of Ms B. Rumler, Ms B. Hasselriis, and Ms E. Greve Petersen is gratefully acknowledged.

\section{References}

1 Veys E M, Hermanns P, Verbruggen G, Schindler J, Goldstein, G. T lymphocytes in blood and synovial fluid in rheumatoid arthritis. Lancet 1982; i: 225-6.

2 Chattopadhyay C, Chattopadhyay H, Natvig J B, Mellbye O J. Rheumatoid synovial lymphocytes lack concanavalin-Aactivated suppressor cell activity. Scand J Immunol 1979; 10: 479-86.

3 Strelkauskas A J, Callery R T, McDowell J, Borel Y, Schlossman S F. Direct evidence for loss of human suppressor cells during active autoimmune disease. Proc Natl Acad Sci USA 1978; 75: 5150-4. 


\section{Binderup}

4 Abdou N I, Sadawa A, Pascual E, Hebert J, Sadaghee S. Suppressor T-cell abnormality in idiopathic systemic lupus erythematosus. Clin Immunol Immunopathol 1976; 6: 192-9.

5 Hodgson $\mathbf{H ~ J ~ F , ~ W a n d s ~ J ~ R , ~ I s s e l b a c h e r ~} \mathrm{K} \mathrm{J}$. Alteration in suppressor cell activity in chronic active hepatitis. Proc Natl Acad Sci USA 1978; 75: 1549-53.

6 Arnason B G W, Antel J. Suppressor cell function in multiple sclerosis. Ann Immunol (Paris) 1978; 129C: 159-70.

7 Thielemans C, Vanhaelst L, De Waele M, Jonckheer M, Van Camp B. Autoimmune thyroiditis: a condition related to a decrease in T-suppressor cells. Clin Endocrinol 1981; 15: $259-63$.

8 Zetterman R K, Woltjen J A. Suppressor cell activity in primary biliary cirrhosis. Digestive Diseases and Sciences 1980; 25: 104-7.

9 Hodgson H J F, Wands J R, Isselbacher K J. Decreased suppressor cell activity in inflammatory bowel disease. Clin Exp Immunol 1978; 32: 451-8.

10 Talal N, Steinberg A D. The pathogenesis of autoimmunity in New Zealand black mice. Current topics in microbiology and immunology. Berlin: Springer, 1974.

11 Krakauer R S, Waldmann T A, Strober W. Loss of suppressor cells in adult NZB/NZW mice. J Exp Med 1976; 144: 662-73.

12 Pearson C M. Experimental models in rheumatoid disease. Arthritis Rheum 1964; 7: 80-6.

13 Binderup L, Bramm E, Arrigoni-Martelli E. Splenic suppressor cells in adjuvant arthritic rats: effect of D-penicillamine. Agents Actions 1980; suppl 7: 199-203.
14 Binderup L, Bramm E, Arrigoni-Martelli E. Immunological effects of D-penicillamine during experimentally induced inflammation in rats. Scand J Immunol 1980; 12: 239-47.

15 Binderup L, Bramm E, Arrigoni-Martelli E. Effects of antirheumatics on lymphocytes in culture. Drugs under Experimental and Clinical Research 1977; 2: 181-8.

16 Yam L T, Liand C Y, Crosby W H. Cytochemical identification of monocytes and granulocytes. Am J Clin Pathol 1971; 55: 283-90.

17 Waksman B H, Pearson C M, Sharp J T. Studies of arthritis and other lesions induced in rats by injection of mycobacterial adjuvant. J Immunol 1960; 85: 403-17.

18 Ryzewska A G. Influence of lymphatic tissue on the development of adjuvant-induced polyarthritis in rats. Ann Rheum Dis 1967; 26: 506-16.

19 Katz L, Piliero S J. A study of adjuvant-induced polyarthritis in the rat with special reference to associated immunological phenomena. Ann N Y Acad Sci 1969; 147: 515-36.

20 Piatier-Tonneau D, Mach $\mathbf{P}$ S, Kahan A, Delbarre F. T-suppressor lymphocytes regulation of adjuvant arthritis in two inbred strains of rats. Clinical Rheumatology 1982; 1: Eular Workshop on Rheumatology Research.

21 Noeva K. Antigammaglobulin antibodies in experimental adjuvant arthritis. Allerg Immunol (Leipzig) 1979; 25: 132-9.

22 Binderup L. Lymphocyte-macrophage co-operation during induction of $\mathrm{T}$-suppressor cell activity in rats with adjuvant arthritis. Ann Rheum Dis 1983; 42: 687-92. 